\title{
Student Career Choices before and during Quarantine Measures
}

\section{Opciones profesionales de los estudiantes antes y durante las medidas de cuarentena}

\author{
Svetlana Viktorovna Panina* \\ M.K. Ammosov North-Eastern Federal University, Yakutsk, Russia \\ ORCID: https://orcid.org/0000-0002-4332-7295 \\ Suola Nikolaevna Arkhipova \\ M.K. Ammosov North-Eastern Federal University, Yakutsk, Russia \\ ORCID: https://orcid.org/0000-0002-6057-1206 \\ Tatiana Alexseevna Parnikova \\ Arctic State Agrotechnological University, Yakutsk, Russia \\ ORCID: https://orcid.org/0000-0001-8142-5737 \\ Evdokya Stepanovna Sergina \\ Arctic State Institute of Culture and Arts, Yakutsk, Russia \\ ORCID: https://orcid.org/0000-0002-0933-2322 \\ Marina Vladimirovna Sleptsova \\ Arctic State Institute of Culture and Arts, Yakutsk, Russia \\ ORCID: https://orcid.org/0000-0003-2361-9829
}

Received 07-12-20 Revised 07-25-20 Accepted 09-15-20 On line 09-22-20

*Correspondence

Email: svetlana-panina@autorambler.ru
Cite as:

Panina, S. V., Arkhipova, S. N., Parnikova, T. A., Sergina, E. S., \& Sleptsova, M. V. (2020). Student Career Choices before and during Quarantine Measures. Propósitos y Representaciones, 8 (SPE3), e711. Doi: http://dx.doi.org/10.20511/pyr2020.v8nSPE3.711 


\section{Summary}

Nowadays, in terms of the COVID-19 pandemic, there is a dramatic transformation of the professions in demand and labor market preferences. In this regard, universities need to review and pay special attention to young people's professional development taking into account new conditions. In February 2020, before quarantine in the Russian Federation, the authors of the present research conducted a survey in order to study the students' career preferences. The survey involved 616 students of Bachelor's and Master's programs of M. K. Ammosov NorthEastern Federal University ("My professional career"), 78 students of the Arctic State Agrotechnological University ("Labor values of youth"), 29 students of the Arctic State Institute of Culture and Arts ("Me and my professional career"). The results showed that the students consider career development as an opportunity to realize their material goals, to combine professional and personal interests, and to set up their own business. In addition, during a quarantine measures due to the COVID 19 pandemic in May 2020, an express survey of 437 students was conducted. The results of the survey showed that some students have changed their attitude to their future career, i.e., they wanted to get advanced professional education, improve their digital skills to make it easier to adapt for remote work. Some students expressed their thoughts regarding future employment, i.e., a budget organization or the sphere of small and medium businesses. The authors concluded that university programs for future specialists' training should take into account students' career preferences, desires, professional intentions and attitudes.

Keywords: Professional Career; Higher Education Institution; Students' Preferences; Quarantine; COVID 19 Pandemic.

\section{Resumen}

Hoy en día, en términos de la pandemia COVID-19, hay una dramática transformación de las profesiones en demanda y preferencias del mercado laboral. En este sentido, las universidades deben revisar y prestar especial atención al desarrollo profesional de los jóvenes teniendo en cuenta las nuevas condiciones. En febrero de 2020, antes de la cuarentena en la Federación de Rusia, los autores de la presente investigación realizaron una encuesta para estudiar las preferencias profesionales de los estudiantes. En la encuesta participaron 616 estudiantes de los programas de licenciatura y maestría de la Universidad Federal del Nordeste M. K. Ammosov ("Mi carrera profesional"), 78 estudiantes de la Universidad Estatal Agrotecnológica del Ártico ("Valores laborales de la juventud"), 29 estudiantes del Instituto Estatal del Ártico de Cultura y Artes ("Yo y mi carrera profesional"). Los resultados mostraron que los estudiantes consideran el desarrollo de la carrera como una oportunidad para realizar sus objetivos materiales, combinar los intereses profesionales y personales y crear su propio negocio. Además, durante las medidas de cuarentena debidas a la pandemia de COVID 19 en mayo de 2020, se realizó una encuesta expresa a 437 estudiantes. Los resultados de la encuesta mostraron que algunos estudiantes han cambiado su actitud hacia su futura carrera, es decir, querían obtener una educación profesional avanzada, mejorar sus habilidades digitales para facilitar su adaptación al trabajo a distancia. Algunos estudiantes expresaron sus ideas sobre el futuro empleo, es decir, una organización presupuestaria o la esfera de las pequeñas y medianas empresas. Los autores concluyeron que los programas universitarios para la formación de futuros especialistas deberían tener en cuenta las preferencias de carrera, los deseos, las intenciones y las actitudes profesionales de los estudiantes.

Palabra clave: Carrera profesional; institución de educación superior; preferencias de los estudiantes; cuarentena; Pandemia de COVID 19. 


\section{Introduction}

Nowadays, changes that take place in one part of the world influence everyday life on a global scale. People's life goals and professional aspirations have changed due to the COVID-19 pandemic. This virus has caused enormous demographic and economic damage to leading states. As a result, we can discern people's priorities. For example, if a person's main concern is to stay at home, remain indoors unless necessary, and order products through a delivery service, i.e., to isolate himself or herself completely, then the person's most important values are health and responsibility to others. If people continue going to work, they are focused on money and career. Currently, the younger generation is heavily influenced by the current crisis since their long-term goals are being formed based on their life objectives (Borisova \& Vasilieva, 2020). Therefore, the successful socialization and the professional development of graduates of Russian and foreign universities are hampered by the present reality (Zalutskaya, 2019).

The extreme conditions of the forced transition of all forms of Russian education to distance learning has revealed that distance learning, despite its grounding in Russian pedagogical theory and practice, does not meet the educational needs of the teachers nor of the students (Vayndorf-Sysoeva \& Subocheva, 2020). Therefore, teachers must be able to organize training, to apply time management skills and to organize, implement, evaluate, and adjust the training process, contributing to the reevaluation of the career process.

While the problem of uncertainty is acute for all age groups under quarantine, the authors have focused on students. On the one hand, this category is characterized by its flexibility and its adaptability to the requirements and the pace of modern life. On the other hand, they have insufficient life experience in overcoming difficult situations. For students, each non-standard event is not an act of repetition, but an act of novelty, one that requires search and creation (Sokolovskaya et al., 2020).

Special attention is paid to the issues of professional self-determination of youth in the Russian Federation since at this stage of life, young people start considering themselves as members of a certain professional activity. To promote career objectives and guidance, federal programs are being implemented. These programs include: "You Are an Entrepreneur," (n.d.) aimed at developing personal and professional development skills; "Working Youth," (n.d.) which supports professional development, civic education, leisure time, and young workers' initiatives; and "Professional Trajectories," (2018) which focuses on the implementation of their professional trajectories.

One of the highest priorities of government policy in Russia is the preservation and growth of the human capital of young people, which is impossible without the qualitative development of formal and informal education. It is necessary to develop a system of education that will develop the students' ability to plan for the future, be responsible for it, and believe in themselves, their competencies and the possibilities for self-realization (Chistyakova et al., 2016).

The purpose of this research is to study university students' ideas about careers, occupational preferences, and methods and techniques of career development in light of the specific conditions in the northeast and in the Far North of the Russian Federation. These conditions include distance from the nearest settlements, insufficient development or the absence of the Internet, harsh climatic conditions, insufficiently developed infrastructure before and during the quarantine.

The study's objectives are to consider the concepts of "career" and "professional career" in the literature; to study the priorities, life attitudes, and career strategies of university students in the Republic of Sakha (Yakutia) before and during the quarantine; and to consider university 
students' training for career development considering ethnocultural and regional features, and distance learning.

The present research is significant for experts involved in training specialists in higher education institutions and for anyone who is interested in career development issues.

Currently, in the Republic of Sakha (Yakutia), a new educational landscape is being formed, as new formats and models of education are being developed in conjunction with an increase in the number of stakeholders. New technologies and non-standard communication formats have appeared as well as the possibility for online instruction regardless of the student's location (Gharawi et al., 2020). The implementation of national projects such as "Education," (The Ministry of Education of the Russian Federation, n.d.) "Digital Economy," (n.d.) and "Demography" (Ministry of Labour and Social Protection of the Russian Federation, 2018) promote the enhancement of the participants' enrollment. In the recent years, there has been observed a process of collaboration with higher education organizations and the formation of associations and consortia, which have contributed to the attainment of benchmarks in the development of higher education (Panin, 2020).

There are five universities in Yakutia, Russia: M. K. Ammosov North-Eastern Federal University (NEFU), Arctic State Agrotechnological University (ASAU), Arctic State Institute of Culture and Arts (ASICA), Churapchinsky State Institute of Physical Culture and Sports (CSIPCS), and the Budget Educational Institution of Higher Professional Education, V. A. Bosikov Higher School of Music of the Republic of Sakha (Yakutia) (Territorial Authority of the Federal State Statistics Service for the Republic of Sakha (Yakutia), 2016).

The driver of the socio-economic development in the region is NEFU. The university has more than 470 educational programs, in such professional fields as medicine and healthcare, education, construction, geological exploration, oil and gas engineering, mining, transport and road facilities, philology, economics, management, energy, physical education and sports, IT, etc. ASAU provides training programs for specialists in the following areas: agronomy, agricultural engineering, forestry, production technology and processing of agricultural products, veterinary medicine, zootechnics, etc. ASICA provides training programs for specialists in the theatrical sphere, museology and preservation, library science, entertainment industry, the social and leisure sphere, folk art culture, painting, art history, design, etc. It appears that the number, the number of specialist training programs is sufficient for the northeast and the Arctic zone of the Russian Federation.

\section{Literature Review}

Povarenkov in his research declares that there are national differences with regard to studying the concept of "career" across different countries (Povarenkov, 2013). An analysis of scientific works uncovered two models of career development: the Japanese model, in which an employee relocates within the same company (includes, for example, changes in the sphere of activity, horizontal and vertical relocation), and the American model, wherein an employee transfers to another company as part of natural career development (Templar, 2017).

Studies related to career issues use the terms vocational guidance or counseling and career guidance. The career theories of Holland and Krumboltz, among other scholars, are based on interdisciplinary research. They expanded ideas on career behavior and the psychodynamic influence of educational methods on professional interest development (Tsymbalyuk, 2016). 
Table 1.

The Concept of "Career"

\begin{tabular}{ccc}
\hline № & Definition & Researcher \\
\hline $1 . \quad \begin{array}{c}\text { It is caused by psychological neoplasms, } \\
\text { depending on the age of an individual. With } \\
\text { the individual's growth, a career takes on } \\
\text { new meanings (New ambitions and the } \\
\text { possibilities with which they are achieved } \\
\text { prevail.). }\end{array}$ & $\begin{array}{c}\text { S.N. Chistyakova, (Chistyakova, } \\
\text { 2018) }\end{array}$ \\
$\begin{array}{c}\text { A successful career is characterized by self- } \\
\text { awareness, thereby enabling a person to } \\
\text { identify herself or himself with a profession. }\end{array}$ & $\begin{array}{c}\text { P.D. Tiger, B. Barron Tiger } \\
\text { (Lesnikova \& Leukhova, 2018) } \\
\text { S.I. Sotnikova (Sotnikova \& } \\
\text { 3. } \quad \begin{array}{c}\text { Sotnikov, 2015) } \\
\text { There is an opportunity to choose an }\end{array} \\
\text { educational trajectory according to an } \\
\text { individual's abilities and a society's needs. It } \\
\text { is the result of their own professional } \\
\text { strategy. }\end{array}$ & $\begin{array}{c}\text { D. Dreyfus, L. Cramer-Hayon et al. } \\
\text { (Tsymbalyuk, 2016) }\end{array}$ \\
\end{tabular}

A professional career is a process by which a person's work life goes through various stages of development, including the professional choices that make up one's biography, professional training, job acquisition, and professional promotion. A necessary task is to realize that career development starts at the moment one selects a professional sphere in which to operate rather than at the moment of appointment to a position. Therefore, the appropriate selection of a profession is the fundamental factor for a successful career.

As rightly declared by Belbin (1997) and Sotnikova and Sotnikov (2015), professional success depends on the ability to overcome contradictions between the individual and the professional environment. Individual (biological factors), personal (psychological characteristics), and professional development (socio-economic factors) stages proceed at uneven levels. Thus, each person treads his or her own unique professional path. Researchers identified and distinguished types of professional careers on the basis of the correlation among individual, personal, and professional development (Belbin, 1997; Sotnikova \& Sotnikov, 2015) (Table 2).

Table 2.

Classification of Professional Careers

\begin{tabular}{|c|c|c|}
\hline $\begin{array}{l}\text { Type of professional } \\
\text { career }\end{array}$ & Characteristics & $\begin{array}{c}\text { Interaction among individual, } \\
\text { personal, and professional } \\
\text { development }\end{array}$ \\
\hline Adaptive & $\begin{array}{c}\text { Professional interests, } \\
\text { inclinations, and abilities are } \\
\text { absent or not demonstrated. }\end{array}$ & $\begin{array}{l}\text { Individual development does not } \\
\text { create conditions for personal and } \\
\text { professional development. }\end{array}$ \\
\hline $\begin{array}{l}\text { Professionally } \\
\text { reproductive }\end{array}$ & $\begin{array}{l}\text { There is no concern for } \\
\text { competitiveness, and } \\
\text { professional achievements are } \\
\text { penultimate. }\end{array}$ & $\begin{array}{l}\text { Personal development is more } \\
\text { intense than individual and } \\
\text { professional development. }\end{array}$ \\
\hline $\begin{array}{l}\text { Personally productive } \\
\text { (competitive) }\end{array}$ & $\begin{array}{l}\text { Professional achievements } \\
\text { satisfy the need for self- } \\
\text { assertion, cause the } \\
\text { restructuring of professional } \\
\text { self-awareness, and influence } \\
\text { the system of motives and pre- }\end{array}$ & $\begin{array}{c}\text { Professional development } \\
\text { prevails. }\end{array}$ \\
\hline
\end{tabular}


structural qualities of an individual.

Subjectively and creatively professional
Optimal balance occurs, thus contributing to implementation.
There is a relative correspondence of the rates of individual, personal, and professional development.

The analysis of theory and practice contributed to the identification of the following mechanisms of career process: internal sources (activity, human drivenness), external sources (social environment, its needs and interests, etc.), and competition as a selection tool. In this regard, students should be aware of aspiration levels, which significantly influence career mastery. The authors of the present research defined the following aspiration levels: real aspiration (covers qualities such as confidence, will, perseverance, productivity, criticality), overestimated aspiration (encompasses the choice of goals that are excessively easy or difficult to achieve), and underestimated aspiration (includes high anxiety, self-doubt) (Gromova et al., 2012; Gonchar \& Ognev, 2017; Didkovskaya, 2014; Martyshenko, 2017).

Currently, universities pay attention to issues of graduate employability even as these institutions provide insufficient psychological and pedagogical support for the development of career skills that can considerably help them after they complete their education (Yamen, 2019). At the pre-professional stage, a necessary requirement is to motivate young people to study at universities and build a career. As declared by Fuller (2020), a student at International Polytechnic High School in Pomona:

I'm still in high school, but the most stressful thing in my life is college. I would have to say the single most stressful thing in my life for the past six months has not been finals, relationships, or presentations. It has been college. A career. The question of: What the hell am I, a 15-year-old who doesn't even know how to drive a car yet, going to do with the rest of my life? It's an important question. And everyone has to answer it at some point. But a lot of people go to college without answering it. A lot of people get a job without answering it. A lot of people have no idea where they are going, but keep on living anyway.

In this regard, the authors of the present study adopted the ideas of Conley (2014), a Professor of Educational Policy and Leadership as well as a founder and a director of the Center for Educational Policy Research (CEPR) at the University of Oregon. Being also a founder, chief executive officer, and chief strategy officer of the Educational Policy Improvement Center (EPIC) and the president of EdImagine Strategy Group, both in Eugene and Portland in Oregon, he shared the following sentiments:

A college- and career-ready student possesses the content knowledge, strategies, skills, and techniques necessary to be successful in any of a range of postsecondary setting. Success is defined as the ability to complete entry-level courses at a level of performance that is sufficient to enable students to continue to the next courses in their chosen field of study. Not every student needs exactly the same knowledge and skills to be college and career ready. A student's college and career interests help identify the precise knowledge and skills the student needs (Conley, 2014).

\section{Methods}

Research methods include a content analysis of the scientific literature on professional careers as well as psychological and pedagogical support for the development of the students' career competencies. In addition, the authors applied the generalization of the best practices, an analytical study using focused observation, questionnaires and a survey of the students. 
Thus, "Professional Career" survey was conducted in February 2020. It involved 616 students of NEFU (64.4\% - girls and 35.6\% - young men). Among respondents, $87.8 \%$ were future bachelors and $11.5 \%$ - the students of the master's program.

Among the students of ASAU, a survey "Work values of the Youth" was conducted. It involved 78 students of the years from the 1st to the 4th of the Faculty of Engineering, majoring in "Agricultural engineering" (young men - $78.7 \%$ and $21.3 \%$-girls).

The students of the $3^{\text {rd }}$ and $4^{\text {th }}$ years (29 people) of the Department of Cultural Studies and Socio-Cultural Activities, the Department of Folk Art Culture and the Department of Library and Information Activity and Humanitarian Disciplines of ASICA answered the questions of the questionnaire "Me and my professional career."

In order to study future specialists' opinion on the career opportunities under quarantine for the COVID 19 pandemic, an express survey was conducted by means of the Google Forms application in May 2020. The survey involved 437 students. Among them, there were 368 students of NEFU, 49 - of ASAU, and 20 - ASICA.

\section{Results}

The relevance of the problem of university support in student career development was approved by content analysis of scientific research in the field of professional pedagogy, as well as the study of Russian university activity in relevant aspects.

Regarding the results of a survey of the students of NEFU, the authors were interested in the students' understanding of such terms as "career", "procedure and mechanisms for career building", and "competencies, necessary for a successful professional career". Therefore, $88.1 \%$ of students answered positively and $8.8 \%$ negatively to the question: "Do you think it is necessary to be a career-oriented person in modern conditions?" The question: "Do you think it is necessary to plan your professional career before entering a university?" was answered the following ways: (bachelor-master)";

$57.8 \%$ of the students answered "yes, in order to undergo sequential training

- $\quad 28.9 \%$ of the students answered "it's not necessary, the main thing is to get a higher education, to graduate from a university, since skills are important";

and $13 \%$ of the survey participants answered they "need to work in the field of study, and make a decision afterwards."

Among the respondents (616 students), 24.2\% combined work with studying, with $54.4 \%$ only studying and $21 \%$ having a part-time job. The respondents gave the following answers to the question: "What are you striving for during your studies at the university?":

- $65.4 \%$ of the students answered "to gain knowledge, skills and competencies";

- $10.1 \%$ of the students wanted "to build social ties". Just several percent of the students noted "studying at the senior courses makes it possible to combine work and studying", "to undertake international internships," "to start a business as a part of project activity".

The researchers obtained the following answers to the question: "What is a successful professional career associated with?"

- $\quad$ "to be able to accomplish material goals, to earn a lot" (52.4\%);

- "to be able to combine professional and personal interests, such as sports, creativity, etc."(49\%); 
- $\quad$ "to have an opportunity to realize professional goals and personal qualities, implement a project, to influence decision making" (46.3\%);

"to set up own business and work for oneself" (42.4\%);

"to become a company's chief executive and to handle a staff" (32\%).

The students under the survey identified the following competencies, which they considered to be necessary for career development (Table 3). Thus, $83.9 \%$ considered practical skills as important in the professional sphere, $72.7 \%$ emphasized sociability and teamwork, $60.9 \%$ of the students suggested creative potential, and $50.6 \%$ of the students highlighted deep fundamental knowledge in the professional field.

Table 3.

"What Competencies are Necessary to Build a Career?" (\%)

\begin{tabular}{|c|c|c|}
\hline № & Competencies & Number of answers \\
\hline 1. & $\begin{array}{l}\text { Practical skills and abilities in the } \\
\text { professional field }\end{array}$ & 83.9 \\
\hline 2. & $\begin{array}{l}\text { Sociability, ability to work in a team } \\
\text { (collective) }\end{array}$ & 75.2 \\
\hline 3. & Creativity, creative approach & 60.9 \\
\hline 4. & $\begin{array}{l}\text { Fundamental knowledge in the professional } \\
\text { field }\end{array}$ & 57.1 \\
\hline 5. & Systemic and analytical thinking & 50.6 \\
\hline 6. & Digital competency & 32.8 \\
\hline 7. & Critical thinking & 31.3 \\
\hline
\end{tabular}

Regarding the future career, $37.8 \%$ of students noted that they did not make any special efforts and hoped for employment immediately after the graduation; $25.6 \%$ of university students drew up and are already implementing their personal and professional plans; $23.9 \%$ of the respondents were actively engaged in research and public work, as they were sure that this was necessary for their professional portfolio; some of the students were getting advanced professional education and $19.2 \%$ were going to do it in their last years (Table 4).

Table 4.

"How Do You Prepare for a Future Professional Career?"

\begin{tabular}{ccc}
\hline № & Answers & Number of Answers \\
\hline $1 . \quad \begin{array}{c}\text { "I do not do anything, I think that I will find a job } \\
\text { and vocation after the graduation" } \\
\text { "I have drawn up a plan of personal and } \\
\text { professional growth for myself, and I am } \\
\text { 2. }\end{array}$ & 25.6 \\
consistently implementing all the planned activities, \\
and participating in project activity" \\
3. I am actively engaged in public and research \\
work, I believe that it is necessary for my \\
professional portfolio"
\end{tabular}




\begin{tabular}{|c|c|c|}
\hline & competencies" & \\
\hline 7. & $\begin{array}{l}\text { "I attend clubs and elective course in terms of my } \\
\text { training program" }\end{array}$ & 15.4 \\
\hline 8. & $\begin{array}{l}\text { "I attend clubs, workshops conducted by } \\
\text { associations, creative studios, etc., for the social } \\
\text { ties development" }\end{array}$ & 13.6 \\
\hline 9. & $\begin{array}{c}\text { "I always take part in all initiatives, I develop my } \\
\text { digital account. I am sure that employers and } \\
\text { partners will value it. It is necessary for my } \\
\text { business (startup)" }\end{array}$ & 8.4 \\
\hline 10. & $\begin{array}{l}\text { "I am going through interviews, participating in } \\
\text { competitions for increased scholarships from } \\
\text { enterprises and organizations" }\end{array}$ & 3.2 \\
\hline
\end{tabular}

The results of the questionnaire survey of ASAU students showed that $28.2 \%$ of them combined work with studying, $68.7 \%$ studied, and $3.1 \%$ of the respondents had a part-time job. Answering the question "What, in your opinion, has the greatest impact on the formation of the youth's labor values?", future agrarians highlighted "schooling and vocational education" (53.8\%); "professional experience" (48.7\%); "family upbringing" (44.9\%); "public opinion" (33.3\%); "friends and relatives' opinion" (32.1\%); "availability of production in the region" (24.4\%); "media, Internet" (23.2\%).

The survey results showed that $83.3 \%$ of future agro-engineers ranked "family" as the highest in the values hierarchy; $59 \%$ of the students emphasized "health", $53.8 \%$ of the students indicated "career", "self-development" and "education" were noted by $44.9 \%$ and $42.3 \%$, respectively (Table 5).

\section{Table 5.}

Significant Life Values of the Students (\%)

\begin{tabular}{ccc}
\hline № & Values & Number of Answers \\
\hline 1. & Family & 83.3 \\
2. & Career & 53.8 \\
3. & Health & 59 \\
4. & Self-development & 44.9 \\
5. & Education & 42.3 \\
6. & Leisure time and entertainment & 24.4 \\
7. & Freedom & 21.8 \\
8. & Labor & 19.2 \\
9. & Creativity & 15.4 \\
10. & Science & 10.3 \\
11. & Independence & 10.3 \\
12. & Power & 6.4 \\
\hline
\end{tabular}

According to the survey results, greater part of the students $(67.9 \%)$ noted that the most important component of their future job was "the possibility of career growth". The necessity of the creativity of work and the availability of an adaptation system was emphasized only by $26.9 \%$ of the students (Table 6). 
Table 6.

"What is the Most Important to You in Your Future Job?"

\begin{tabular}{ccc}
\hline$№$ & Answers & Number, \% \\
\hline 1. & "Possibility of career growth" & 67.9 \\
2. & "Job prestige" & 55.1 \\
3. & "Possibility for training and development & 42.3 \\
\multicolumn{4}{c}{ opportunity" } \\
5. "Work should contribute to my professional growth" & 30.8 \\
6. & "Work must be creative" & 26.9 \\
\hline
\end{tabular}

The survey showed that $65.4 \%$ of the students defined "confidence" as the most important quality for the young people's professional success. However, such characteristic as "sociability", "well-bred speech" and "kindness" were considered as insignificant (15.4\%, $14.2 \%$ and $6.7 \%$ respectively) (Table 7 ).

Table 7.

"Qualities, Necessary for Professional Success"

\begin{tabular}{ccc}
\hline № & Qualities & Number, \% \\
\hline 1. & Confidence & 65.4 \\
2. & Industriousness & 62.8 \\
3. & Perseverance, persistence & 41 \\
4. & Honesty & 37.2 \\
5. & Courage & 30.8 \\
6. & Professional competence & 29.5 \\
7. & Independence & 20.5 \\
8. & Sociability & 15.4 \\
9. & Well-bred speech & 14.2 \\
10. & Kindness & 6.7 \\
\hline
\end{tabular}

According to the survey, most respondents (54.7\%) attributed "lack of necessary knowledge and skills" as the main difficulty in realizing their professional needs and building a career. At the same time, only $26.7 \%$ of the students regarded "unsatisfying salary" as the obstacle for their career development (Table 8).

Table 8.

"What Prevents Youth from Fulfilling Their Professional Needs and Building a Career?"

\begin{tabular}{ccc}
\hline № & Answers & Number of Answers, \\
$\%$
\end{tabular}

The results of the survey among the students of ASICA aimed at identifying the features of a professional career building for future specialists in creative professions with different 
ethnocultural identities revealed that students regard professional career as "social ascent", "career advancement", or "fame in their region and beyond its limits". Moreover, a lot of students defined career growth rather as salary increase than personal self-development in professional activity. In addition, $68 \%$ of the students believed that career was their realization in profession. This means that students only tend to achieve personal success in the profession, although do not take into account the society needs, do not know the demand for the chosen profession in the labor market. Therefore, they have difficulties with employment. In order to build a successful career, students consider it necessary to develop ideas for their own business, to get an advanced education, and to build social ties.

In May 2020, during the period of quarantine measures, an express survey was conducted which involved 437 students. The purpose of the survey was to find out whether the students' attitude towards their future professional activity, their views and motivation, difficulties or the success have changed while studying remotely. The respondents were offered to answer the question "How do you look to the future?" Thus, $61 \%$ of the students answered like "hoping that the quarantine will end soon, I will go out to study, and will continue my future profession training." Another part (17\%) said that they "are anxious and fatigue, because of doubt about the career choice, since it is impossible to work in my profession in such conditions". Some respondents (13\%) noted "it is necessary to get one more profession". At the same time, $47 \%$ of the students believed they needed to improve their knowledge of information and communication technologies and digital tools, while $24 \%$ of the students admitted that it was necessary to enhance their self-management skills. Almost $18 \%$ of the students started thinking about changing their future profession, since in such conditions there would be no demand for the chosen profession.

While answering the question "What do you do under quarantine?", the students said that basically, besides studying remotely, they watched movies on the Internet, played computer games, read books, listened to music, and helped relatives with the household, since most students live in rural areas. To enhance self-development and professional self-determination, some students gained additional knowledge via online courses and webinars introduced by leading universities, large companies, firms, well-known experts and specialists (1C, Mail.ru Group, Yandex, Sberbank, etc.)

It is worth highlighting that there were students who helped the elderly and single people, people with disabilities, large families having problems. Students joined volunteer groups at the place of residence, providing food and medicine provision, walking pets, etc. Moreover, they helped families of the medical workers who spent weeks in medical institutions assisting patients with the COVID 19 virus. Students of pedagogical departments practiced online, consulted schoolchildren on academic subjects, homework, etc. There were also students who found a job through the Internet during quarantine. They sold and delivered groceries. However, some students "slept off" and did nothing. Unfortunately, some of them did not even study.

The authors of the present study also considered the psychological aspects of being in self-isolation. In this regard, they asked the students whom they would like to restore relations first, as they were before pandemic. Most students (57\%) noted friends, 29\% - their student group, $26 \%$ - relatives and close people, $18 \%$ - teachers, $17 \%$ - a romantic partner. Only $8 \%$ of the students declared that they would not like to restore relations with anyone, since they were quite happy in new communication format.

The respondents emphasized the following things that scare them most of all, namely: contracting an unknown disease; videos and statistics on dead and infected people; controversial information about the virus and its treatment due to a great amount of fakes; anxiety about uncertainty after the pandemic. 
The problem of IT availability was also significant for remote studying. More than a half of the students $(59 \%)$ considered that they were fully provided with equipment, $12 \%$ were almost provided and $29 \%$ were insufficiently provided. The students were asked to evaluate their skills for working on online learning platforms (Zoom, Microsoft teams, Skype, etc.) according to five-point scale (" 1 " is bad and " 5 " is excellent). Thus, only $5 \%$ of the respondents rated 1 point, $27 \%$ - 2 points, $29 \%$ - 3 points, $31 \%$ - 4 points and $8 \%-5$ points.

\section{Discussion}

The professional career choice is one of the most significant decisions in life. Preparing students for a professional career is a complicated, complex and integrative problem. It includes the following aspects: pedagogical, psychological, psychophysiological and social. Achievements in a particular sphere of life depend on the correlation between personality and work features, the compatibility of personal expectations about the career with successful adaptation in a professional environment.

The future specialist's training involves the development of such forms and methods of education that contribute to the formation of the characteristics that are adequate for future professional activity and motivate to realize personal and professional capabilities as a moral basis for future career growth (Chistyakova, 2018).

The universities of the Republic of Sakha (Yakutia) have managerial units that assist students in their professional development, career building and employment. Thus, a career center is functioning in NEFU with the goal of providing informational and counseling support, students' temporary employment and monitoring the graduates' employment. According to the specialists of the center, in terms of the COVID 19 pandemic, the demand for online sales specialists, PR managers, programmers and designers has grown. In this regard, the center is reviewing and upgrading its activities.

The workers of the pedagogical institute of NEFU actively develop the electronic portal "School Student - Applicant - Student - Young Specialist - Mentor", which is a center for the consolidation of various information resources and services. An important element of the portal is the Career Navigator, which allows interactive counseling of applicants, students and their mentors. Career Navigator frames have a link to a tool for real-time communication, which allows asking questions online, with the connection of a Virtual Digital Assistant, which answers standard questions. Communication with employers (graduate - employer interaction) is organized through targeted training for organizations basing on the analysis of the employer's requirement for a competent specialist. In cooperation with ministries, departments of the Republic and other stakeholders we develop register of currently relevant vacancies for qualified specialists, taking into account their professional skills, experience and education, as well as a description of the further employment mechanism. Moreover, the university creates an educational resource center, different educational schemes within the framework of the schoolcollege-university system, making it possible to create a unified system of continuous professional education according to personality trajectories (Panin, 2020).

The specialists of the career center implement methods and technologies, which are specific only to distance learning. Over the past few months, a "digital workshop" has become popular among students, i.e., a collective discussion of the problem with the participation of the experts. This digital format includes texts, time line, a mental map, and other digital instruments. The topics range from creating a team to develop projects in the Internet to management skills training.

There is a department for employment and internship in ASAU. In terms of distance learning due to the pandemic, the specialists of this department provide webinars for students on career development issues, consult on vacancies in the regional labor market and on resume 
preparation. In addition, they organize video conferences with the employers and representatives of the Republic authorities.

In ASICA, the educational department handles the issues of career development and employment. Currently, these kinds of universities come across a lot of difficulties in terms of distance learning. Their activity includes the performances, concerts, shows, exhibitions, and entertainment projects, where the presence of potential employers should be mandatory. Now, students present videos about preparatory work and internship, virtually present their creative ideas and projects. Then video materials are watched by university teachers and representatives of cultural and art institutions. Thus, the students of the department of theatrical art underwent on-line undergraduate internship in republican theaters such as the State Variety Theater, the Young Spectators' Theatre, the Theater of Indigenous Minorities of the North, the Olonkho Theater, the State Academic Russian Drama Theater, and Sakha P.A. Oyunsky Academic Theatre. Video reports about diploma internship were posted on the websites of the theaters and the institute.

The results of the survey conducted during the quarantine indicated that it necessary to improve the psychological component of specialists' training through individual psychological and pedagogical consultations, to expand and demonstrate the possibilities of the labor market and temporary employment, to organize webinars on resume preparation and self-presentation for meetings with employers

\section{Conclusion}

The COVID 19 pandemic caused dramatic changes in key public institutions. However, this is rather new reality, which is based on the technological revolution, as experts call it "industry achievements 4.0 " than wreckage.

In addition, there is a radical change in the labor market, the number of office workers and retailers is reduced, health systems are being updated, etc. There is a demand for IT specialists.

However, the experience of living in a pandemic is not always negative. It is also a challenge to go beyond the boundaries of the situation, to mobilize, to be able to define the main thing in our lives, to set priorities, to take a fresh look at what we did not value, to increase our vitality, and to master new forms of living (Shavykina, 2020).

Currently, economic and epidemiological situations require psychological and pedagogical support for building the careers of the future specialists. It is necessary to introduce online and offline career coach and partnership with mentors and experts. Students would carry out projects, research, and gain professional and social experience.

Moreover, it is necessary to involve students in volunteering, to attract potential employers to teaching and to certification commissions work, to intensify the work on the organization of the students' internship at enterprises and factories.

In the context of unemployment growth caused by the pandemic, especially among young people, it is necessary to organize psychological and pedagogical support for students (interactive exercises, business games, brainstorming, discussions, disputes, etc.) that would make them easier to enter the labor world, as well as to develop skills for mastering competitive technologies.

Sample in future empirical studies on the students' motivation and orientation should be expanded in order to obtain more holistic picture of young people's career attitude in the Russian Federation and abroad. 


\section{References}

Belbin, R. M. (1997). Team roles and self-assessment of your preferred roles. Effective manager: Views and illustrations. Zhukovsky: MCDO LINK.

Borisova, U. S., \& Vasilieva, A. I. (2020). Students' life values in the elite school "Republican Lyceum-Boarding school”. Society: Sociology, Psychology, Pedagogy, 4(72), 20-23.

Chistyakova, S. N. (2018). Professional career development as the most important resource for the adaptation of a graduate in the labor market. Bulletin of Voronezh State University: Series: "Problems of Higher Education", 3, 199-202.

Chistyakova, S. N., Gevorkyan, E. N., \& Podufalov, N. D. (2016). Current problems of vocational and higher education. Moscow: Publishing House "Econ-Inform".

Gonchar, S. N., \& Ognev, A. S. (2017). The formation of students' subjectivity at the initial stage of professional training through an adaptation program. Bulletin of the Russian New University. Series: Human in the Modern World, 1, 5-9.

Conley, D. T. (2014). New conceptions of college and career ready: A profile approach to admission. Journal of College Admission, 223, 12-23.

Didkovskaya, Ya. V. (2014). Dynamics of youth professional career strategies under conditions of transformation of a professional self-determination model. Bulletin of the Ural Federal University. Series 1. Problems of Education, Science and Culture, 2, 117-131.

Federal Program "You Are an Entrepreneur". (n.d.). [http://molpred.ru/] [Accessed on 4 April, 2020].

Fuller, E. J. (2020). The most stressful thing in my life: when it's time to confront life beyond college. Leadership, 49(5), 18-22.

Gharawi, M. A., Bidin, A., \& Choo, K. A. (2020). Malaysian learners' preferences-based profile model towards adaptive massive open online courses. Journal of Southwest Jiaotong University, 55(1). doi:10.35741/issn.0258-2724.55.1.51

Gromova, E. M., Berkutova, D. I., \& Gorshkova, T. A. (2012). Studies of the attitude of modern Russian students toward professional career planning. Modern Problems of Science and Education, 3. [http://www.science-education.ru/ru/article/view?id=6307] [Accessed on 4 April, 2020].

Lesnikova, S. L., \& Leukhova, M. G. (2018). Professional self-determination of university students as a condition of professional identity: an aspect of attitude to a professional career. Baltic Humanitarian Journal, 7(3(24)), 253-256.

Martyshenko, N. S. (2017). The study of the processes influencing the students' satisfaction with the profession selection. Modern Education, 4, 131-142.

Ministry of Labour and Social Protection of the Russian Federation. (2018). National project "Demography". [https://mintrud.gov.ru/ministry/programms/demography] [Accessed on 3 June, 2020].

National project "Digital economy". (n.d.). [https://futurerussia.gov.ru/cifrovaya-ekonomika] [Accessed on 3 June, 2020].

Panin, S. V. (Ed.). (2020). Professional self-determination of a person: Mechanisms and educational resources. Kirov: Interregional Center for Innovative Technologies in Education.

Povarenkov, Yu. P. (2013). Problems of psychology of professional formation of personality. Saratov.

Program "Working Youth". (n.d.). [https://rudocs.exdat.com/docs/index-287124.html] [Accessed on 3 June, 2020].

Project "Professional Trajectories". [https://www.oprf.ru/files/1_2018dok/4_prezent15052018.pdf] [Accessed on 3 June, 2020].

Shavykina, T. A. (2020). Distance learning in Russia and the USA in a pandemic. In Economics, management and law in modern conditions. Collection of materials (pp. 8286). Tolyatti. 
Sokolovskaya, I. E., Polevoy, S. A., Mikhaylovsky, M. N., Zotov, L. E., Bazhdanova, Y. V., \& Egorova, E. V. (2020). The influence of educational and professional activity on the socialization of students. Opcion, 36(27), 1115-1133.

Sotnikova, S. I., \& Sotnikov, N. Z. (2015). Professional career of the worker: Relevance, essence, types, determinants, indicators of research. Herald of Omsk University. Series "Economics", 1, 100-107.

Templar, R. (2017). The rules of work: A definitive code for personal success. Upper Saddle River, NJ: Financial Times Press.

Territorial Authority of the Federal State Statistics Service for the Republic of Sakha (Yakutia). (2016). Education in the Republic of Sakha (Yakutia): Activity of the vocational education organizations: Statistical digest. Yakutsk.

The Ministry of Education of the Russian Federation. (n.d.). National project "Education". [https://edu.gov.ru/national-project] [Accessed on 3 June, 2020].

Tsymbalyuk, A. E. (2016). Characteristics of main problems of career development psychology. Yaroslavl Pedagogical Bulletin, 6, 233-238.

Vayndorf-Sysoeva, N. E., \& Subocheva, M. L. (2020). Distance learning interms of a pandemic: Problems and ways to solve them. Contemporary Issues in Pedagogical Education, 67(4), 70-78.

Yamen, V. (2019). Development features of the students' career building skills. International Journal of Humanities and Natural Sciences, 7(1), 18-21.

Zalutskaya, S. Y. (2019). Technologies of managing students creative activities: Differentiated instruction. Espacios, 40(17), 22-26. 